\title{
The Emerging Role of Metabolism in Brain-Heart Axis: New Challenge for the Therapy and Prevention of Alzheimer Disease. May Thioredoxin Interacting Protein (TXNIP) Play a Role?
}

\author{
Lorena Perrone $^{1, *}$ and Mariarosaria Valente ${ }^{2,3}$ \\ 1 Department of Advanced Medical and Surgical Sciences, University of Campania Luigi Vanvitelli, \\ 80131 Naples, Italy \\ 2 Department of Medicine, University of Udine, 33100 Udine, Italy; mariarosaria.valente@uniud.it \\ 3 Clinical Neurology Unit, Department of Neuroscience, Azienda Sanitaria Universitaria Friuli Centrale, \\ University Hospital, 33100 Udine, Italy \\ * Correspondence: perronelorena1@gmail.com
}

\section{check for} updates

Citation: Perrone, L.; Valente, M. The Emerging Role of Metabolism in Brain-Heart Axis: New Challenge for the Therapy and Prevention of Alzheimer Disease. May Thioredoxin Interacting Protein (TXNIP) Play a Role? Biomolecules 2021, 11, 1652. https://doi.org/10.3390/ biom11111652

Academic Editor: Marcus O. W. Grimm

Received: 23 September 2021 Accepted: 6 November 2021 Published: 8 November 2021

Publisher's Note: MDPI stays neutral with regard to jurisdictional claims in published maps and institutional affiliations.

Copyright: (c) 2021 by the authors. Licensee MDPI, Basel, Switzerland. This article is an open access article distributed under the terms and conditions of the Creative Commons Attribution (CC BY) license (https:// creativecommons.org/licenses/by/ $4.0 /)$.

\begin{abstract}
Alzheimer disease (AD) is the most frequent cause of dementia and up to now there is not an effective therapy to cure AD. In addition, AD onset occurs decades before the diagnosis, affecting the possibility to set up appropriate therapeutic strategies. For this reason, it is necessary to investigate the effects of risk factors, such as cardiovascular diseases, in promoting AD. AD shows not only brain dysfunction, but also alterations in peripheral tissues/organs. Indeed, it exists a reciprocal connection between brain and heart, where cardiovascular alterations participate to AD as well as AD seem to promote cardiovascular dysfunction. In addition, metabolic dysfunction promotes both cardiovascular diseases and AD. In this review, we summarize the pathways involved in the regulation of the brain-heart axis and the effect of metabolism on these pathways. We also present the studies showing the role of the gut microbiota on the brain-heart axis. Herein, we propose recent evidences of the function of Thioredoxin Interacting protein (TXNIP) in mediating the role of metabolism on the brain-heart axis. TXNIP is a key regulator of metabolism at both cellular and body level and it exerts also a pathological function in several cardiovascular diseases as well as in AD.
\end{abstract}

Keywords: brain-heart axis; metabolism; cardiovascular diseases; TXNIP; microbiota

\section{Introduction}

Alzheimer's disease (AD) is the most common form of dementia characterized by progressive memory loss and cognitive decline [1]. Its pathophysiology consists in the accumulation of extracellular amyloid $(\mathrm{A} \beta)$ plaques and intracellular neurofibrillary tangles, which are composed by hyperphosphorylated Tau [2]. AD includes familiar AD (FAD), due to inheritance of autosomal dominant mutations in genes encoding for proteins involved in A $\beta$ production: amyloid precursor protein (APP) or presenilins (PSEN1 and PSEN2). The discovery of the genes responsible for FAD contributed to the postulation of the amyloid cascade hypothesis of AD pathogenesis, which defines a linear causality between $A \beta$ accumulation and AD pathophysiology [3]. However, FAD constitutes only $5 \%$ of total cases of AD, while the large majority are late onset AD (LOAD) [4]. The molecular mechanisms responsible for LOAD are not yet fully elucidated. Several risk factors promote LOAD, with age as the major risk factor [4]. Up to now, only four FDA approved drugs are currently employed in AD patients: memantine, a N-methyl-D-aspartate (NMDA) blocker, and three inhibitors of the cholinesterase (ChEIs): donepezil, galantamine, and rivastigmine. Notably, each drug alone or a combination of ChEIs with memantine, only modestly ameliorate the cognitive deficit in AD patients. It has been developed only another drug for AD, Aduhelm (aducanumab), very recently approved by FDA [5]. This drug 
is an $A \beta$-directed antibody and counteracts $A \beta$ accumulation and its downstream effect. However, the efficacy of such treatment is still debated [6]. A critical point for the discovery of new therapeutic strategies consists in the still incomplete understanding of the specific causes of AD. Thus, it is necessary discover new therapeutic targets for AD. For this reason, several studies are aimed in unveiling the role of metabolism and risk factors in AD onset and progression. In particular, cardiovascular diseases (CVDs) are associated to cognitive decline and participate to AD [7]. In addition, the risk factors for CVDs promote also AD: hypertension [8], diabetes [9], obesity [10], dyslipidemia [11]. In agreement, Asymmentric DiMethyl Arginine (ADMA) plasma levels, which is an excellent biomarker for sporadic small vessels disease (SVD) and indicates early endothelial dysfunction [12], is also a blood biomarker for $\mathrm{AD}$ [13] and its levels correlate with cognitive decline [14].

Several studies reveal that AD is a systemic disease. APP is expressed not only in brain but also in peripheral tissues and $A \beta$ produced in peripheral tissues participates to $\mathrm{AD}$ [15]. In agreement, the Receptor for Advanced Glycation Endproducts (RAGE), which transports peripheral $A \beta$ into the brain across the Blood Brain Barrier (BBB), plays a key role in $\mathrm{AD}$ [4]. In addition, $\mathrm{A} \beta$ accumulates also in peripheral tissues, contributing to $\mathrm{AD}$ pathogenesis [16]. Notably, $A \beta$ accumulation in cardiomyocytes parallels cardiac diastolic dysfunction in early onset $\mathrm{AD}$, while in late-onset $\mathrm{AD}$ it is associated to thickening of the left ventricle wall, suggesting a bidirectional link between $\mathrm{AD}$ and cardiac dysfunction [17]. In agreement, recent studies underline a connection between neurodegenerative and cardiovascular diseases, defining the so-called brain-heart axis [18].

In this review we describe the molecular pathways implicated in brain-heart axis and their role in AD. Moreover, we summarize the role of metabolism in altering the brain-heart axis, participating to $\mathrm{AD}$. We summarize also the bi-directional regulation between the composition of the gut microbiota and the pathways modulating the heart-brain axis, impacting on AD progression. We underline the role of these data for the discovery of new molecular targets in $\mathrm{AD}$ and the set-up of new therapeutic strategies. We shed light into the potential role of Thioredoxin Interacting Protein (TXNIP) - the inhibitor of the ROS-scavenger Thioredoxin (Trx) and the regulator of glucose homeostasis [19]—as key regulator of the brain-heart axis and thereby a therapeutic target for $\mathrm{AD}$, by analyzing the putative role of TXNIP in the bi-directional regulation of the brain-heart axis in AD.

\section{TXNIP: Its Function on Metabolism and Brain-Heart Axis}

TXNIP is also called Thioredoxin Binding protein 2 (TBP-2) and Vitamin D Upregulated Protein 1 (VDUP-1) [20]. TXNIP is a 46-kDa ubiquitous protein constituted by 391 amino acid residues and is encoded on human chromosome 1q21.1. TXNIP is the endogenous inhibitor of Trx and induces oxidative stress [20]. Hyperglycemia in vivo and high glucose conditions (HG) in vitro promote TXNIP expression [21], TXNIP plays a pathological role in both type 1 and Type 2 diabetes [20] and is also involved in the pathophysiology of diabetic complications, including diabetic retinopathy [22]. TXNIP possesses an $\alpha$-arrestin domain, which promotes the intracellular trafficking of plasma membrane associated proteins and drives the transport of proteins in different subcellular localizations [23]. Moreover, the $\alpha$-arrestin domain is responsible for the Trx-independent functions of TXNIP. TXNIP is a shuttle protein that can translocate in different subcellular compartments [23]. In the majority of the cells in normal conditions, TXNIP shows a nuclear localization. However, following different stimulations, TXNIP can translocate in other subcellular compartments, where it exerts specific functions [23]. TXNIP may translocate into the mitochondria, where it blocks the ROS scavenger activity of Trx2, leading to oxidative stress [23]. TXNIP also promotes the nuclear translocation of the transcription factor NF-kB, leading to the expression of pro-inflammatory genes [21]. For this reason, TXNIP is considered the link between oxidative stress and inflammation [24]. In the cytoplasm, TXNIP is implicated in the activation of the NLRP3 inflammasome [24]. TXNIP is also a downstream effector of the Receptor for Advanced Glycation Endproducts (RAGE) [25], which mediates the cellular response to pro-inflammatory molecules 
such as S100 calcium binding proteins family, HMGB1, Advanced Glycation Endproducts (AGEs), and $A \beta$ [4]. Furthermore, TXNIP protein levels are highly regulated by the ubiquitin-proteasome system [23].

TXNIP participates to the progression of several diseases of the central nervous system, such as AD, Parkinson Disease (PD), and stroke [26]. TXNIP is over expressed in the hippocampus of various AD mice models, such as APP/PS1 mice [27], 3Tg AD mice [28], and 5xFAD mice [29]. Microarray experiments demonstrate that TXNIP is one of the genes more over-expressed in the hippocampus of AD patients [28], as well as immunohistological studies show that TXNIP is over-expressed in the post-mortem hippocampus of AD patients [29]. It has been suggested that TXNIP is implicated in AD by inducing inflammation through the activation of the NLRP3 inflammasome [26]. In agreement, inflammation through RAGE axis plays a key role in AD [30]. Moreover, studies in vitro and in vivo reveal that TXNIP promotes oxidative damage in an AD contest, leading to tau hyperphosphorylations and subsequent alterations on the neuronal cytoskeleton [29]. Our preliminary data show that silencing of TXNIP in an AD mice model prevents inflammation and altered microglia activation. In addition, our preliminary data suggest that TXNIP plasma levels correlates with cognitive decline [31].

Below we discuss the role of TXNIP in modulating various pathways implicated in the brain-heart axis. We describe the molecular pathways triggered by alterations in TXNIP expression/function, which in turn affect the body and cellular metabolism and alter the brain-heart axis, promoting AD.

\section{The Heart-Brain Axis and the Bi-Directional Connection with AD Role of Txnip}

Several studies demonstrate a connection between AD and cardiovascular diseases. Cardiovascular diseases are risk factors for $\mathrm{AD}$ and induce $\mathrm{A} \beta$ deposition as consequence of diminished cerebral blood flow and enhanced oxidative stress [16]. In addition, it has been demonstrated a positive correlation between heart failure and cognitive decline [16]. Conversely, genetic mutations within PSEN1 and PSEN2 genes, which are responsible for FAD, give raise also to dilated cardiomyopathy, reinforcing the hypothesis that these diseases share common mechanisms [32]. Notably, ApoE4, the major genetic risk factor for $\mathrm{AD}$, is a risk factor for coronary heart disease [33]. ApoE4 carriers show higher plasma cholesterol concentration, which is a risk factor for both $\mathrm{AD}$ and cardiovascular diseases [33]. Interestingly, epigenetic modifications of TXNIP correlate with enhanced risks of cardiovascular diseases [34]. Additionally, the levels of circulating mRNA encoding TXNIP are linked to coronary and heart diseases [35]. Notably, TXNIP is considered a marker of cardiovascular diseases, including myocardial ischemia, hind limb ischemia, and also cerebral ischemia [23]. In addition, TXNIP plays a pathological role in several diseases of the central nervous system, such as AD, Parkinson Disease (PD), and stroke [26]. TXNIP is over expressed in the hippocampus of various AD mice models, such as APP/PS1 mice [27], 3Tg AD mice [28], and 5xFAD mice [29]. Microarray analysis show that TXNIP is one of the genes more over-expressed in the hippocampus of AD patients [28], as well as immuno-histological studies show that TXNIP is over-expressed in the post-mortem hippocampus of AD patients [29]. Below, we summarize the molecular pathways involved AD-related brain-heart axis (Figure 1) and the effect of metabolic AD risk factor on these pathways. We provide evidences that unveil the central role of TXNIP in mediating the effects of metabolism in altering the brain-heart axis and in turn promoting AD. These data, are suggesting a key role of TXNIP in brain-heart axis. 


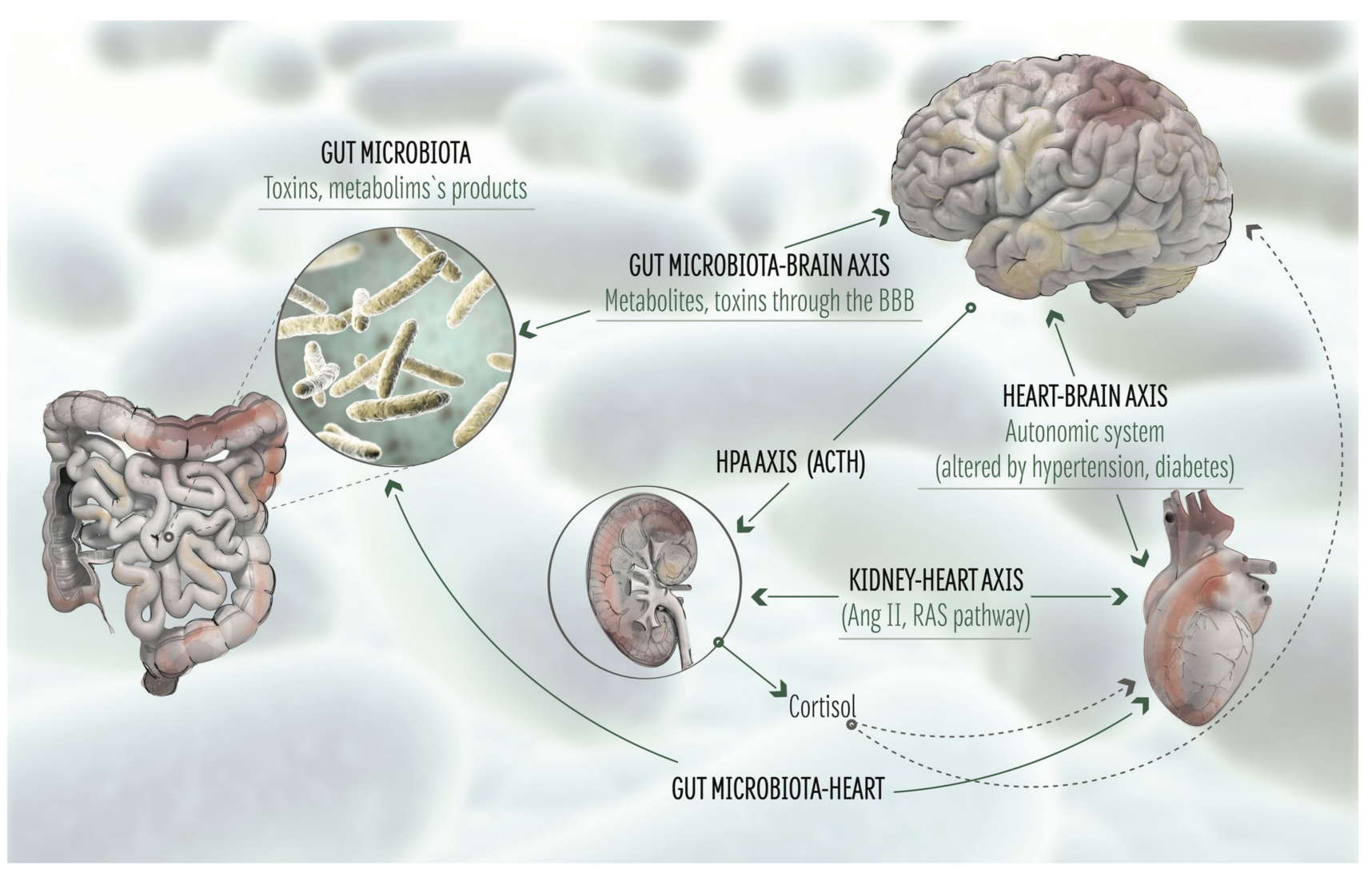

Figure 1. The microbiota-gut-brain-heart axis. Schematic representation of the major pathways implicated in the microbiota-gut-brain-heart axis. BBB: Blood Brain Barrier. HPA: Hypothalamic-pituitary-adrenal axis. ACTH: adrenocorticotrophic hormone. Ang II: angiotensin II. RAS: Renin-Angiotensin system.

\section{The Central Autonomic Network (CAN): Effect on AD}

The anterior cingulate cortex, parabrachial nucleus, hypothalamus, amygdala, periaqueductal grey matter, the anterior insula and some areas of the medulla regulate the cardiac function. The sympathetic and parasympathetic nervous system mediate the function of these cerebral structures in modulating the cardiac activity (the force of contraction and heart rate), representing the responses to emotional events and stress, as well as the homeostatic reflexes [36]. The autonomic systems (sympathetic and parasympathetic structures, suprachiasmatic nucleus, higher nervous centers including some of those involved in depressive and aggressive behavior) have a key function in the control of heart rate variability (HRV), which is implicated in atherosclerosis, arrhythmias, heart failure, myocardial infarction, and sudden cardiac death [37].

Increased sympathetic activity augments the levels of catecholamines, serotonin, renin, cortisol, aldosterone, angiotensin, and free radicals, promoting dysfunction [37]. On the other hands, elevated parasympathetic activity increases the levels of acetylcholine, dopamine, nitric oxide, endorphins, Q10 coenzyme, which exert a protective function [37]. Elevated levels of acetylcholine are protective for the suprachiasmatic nucleus, modulating the sympathetic activity and in turn lowering the risk of myocardial infarction [37]. Cognitive and autonomic processes are linked through the central autonomic network (CAN), which modulates both the cognitive function and the autonomic regulation of cardiovascular function [38]. The CAN is constituted by a network of cortical and subcortical region, including the insula, hippocampus and prefrontal cortex, which projects to the preganglionic neurons of the autonomic nervous system (ANS). Thus, the CAN is widely considered as the neuroanatomic substrate of a brain-heart axis [39]. The analysis of HRV is extensively used in clinical research for the assessment of autonomic function [40]. It has been demonstrated a correlation between HRV and cognitive function in large cohorts of elderly patients [41], as well as in smaller cohorts of AD patients [42]. Neuroimaging 
studies show the presence of atrophy and disrupted functional connectivity of hippocampus and insula in subjects with amnestic mild cognitive impairment (aMCI) and AD [43]. Moreover, these alterations correlate with memory dysfunction [44]. The insula plays a key role within the CAN. In animal models, electrical and chemical stimulation of the insula enhance the heart rate (HR) and blood pressure [45]. In humans, insular activity negatively correlated with parasympathetic HRV [46]. Studies are suggesting a connection also from the hippocampus and the sympathetic system. Functional neuroimaging studies in humans reveal the activation of the hippocampus during sympathetic challenges [47]. In addition, parasympathetic HRV negatively correlates respect to hippocampal activity [46]. Recently it has been described a negative correlation between the activity in the hippocampus and a HRV complexity index [48], further supporting the role of hippocampus in the bi-directional effect between $\mathrm{AD}$ and $\mathrm{CAN}$, affecting the brain-heart axis.

\section{Metabolic AD Risk Factors and Central Autonomic Network: A Bi-Directional Regulation}

The nervous system is implicated in the pathogenesis of obesity and insulin resistance. In particular sympathovagal imbalance, and the relative prevalence of sympathetic activity seem to play a pivotal role in this bi-directional relationship [49]. Several mechanisms have been reported as link between CAN and obesity and insulin resistance, with a special focus on the role of leptin in modulating the energy expenditure and the sympathetic activity [50].

The autonomic network modulates the body weight both in the short and long term through the vagal nervous afferents, which connect the gut to the brain, regulating the sense of satiety and the food intake [51]. Insulin resistance and sympathetic activity also show a bi-directional regulation. Insulin resistance is associated to enhanced basal sympathetic activity that correlates with the degree of insulin resistance, leading to hypertension [52]. Insulin activates the sympathetic activity directly in the brain. During fasting, low plasma levels of insulin lowers insulin-mediated glucose metabolism in hypothalamic neurons, promoting an inhibitory pathway that blocks chronically active sympathetic centers in the brain stem. After carbohydrate intake, the augmented insulin plasma levels promote insulin-mediated glucose metabolism in the same neurons, enhance the glucose metabolism and reduce the inhibitory pathway, resulting in a stimulatory effect of the sympathetic centers at the brain-stem levels [49]. This regulation promotes hypertension in obese subjects, which show insulin resistance on peripheral glucose uptake but are not resistant to the effect of insulin on the sympathetic system [53]. Thus, this circuit promotes hypertension in the presence of insulin resistance, augmenting the of AD. Interestingly, genetic polymorphisms altering TXNIP expression are associated to hypertension [54], arterial stiffness [55], and enhanced risk to developing coronary heart disease [56]. Notably, TXNIP modulates the glucose homeostasis in a Trx-independent manner [57]. Metabolic signals that promote TXNIP, such as HG, inhibit the glucose uptake through the insulin-responsive glucose transporters. TXNIP induces the endocytosis and degradation of the Glut1 [58] and Glut4 glucose transporters [59], blocking the glucose uptake. TXNIP also regulates the glucose utilization, the mitochondrial oxidation of metabolic substrates, and the gluconeogenesis in the liver [23]. These data are suggesting that TXNIP mediates the effect of hypertension and altered insulin signaling on the brain-heart axis, thereby promoting AD.

Leptin - the product of the obese $(\mathrm{ob})$ gene-is a hormone released by the white adipose tissue and it increases the energy expenditure by stimulating the cardiovascular system and the thermogenesis mainly through the arcuate nucleus (ARC) of the hypothalamus [60]. Leptin plasma levels are reduced during fasting, while augment after overfeeding and regulate energy balance by decreasing appetite and increasing energy expenditure through sympathetic stimulation [61], leading to increased arterial blood pressure. Obesity causes elevated levels of circulating leptin as consequence of leptin resistance. The enhanced leptin plasma levels may augment blood pressure, promoting hypertension [62], which is an additional risk factor for AD. Interestingly, a cross-talk between leptin and insulin response has been demonstrated. Leptin improves glucose homeostasis and insulin response [63]. Thus, leptin resistance in obesity may induce insulin resistance, resulting in altered glucose 
metabolism and sympathetic activity. In addition, obesity-induced elevated leptin levels promote a significant alteration of the gliovascular interface in the hypothalamus, causing arterial hypertension [64]. Moreover, obesity promotes the hypothalamic expression of the protease Bace1, which produces elevate levels of hypothalamic $A \beta$ peptide and promotes leptin resistance in the hypothalamus [65].

Leptin receptors are encoded by the diabetes $(\mathrm{db})$ gene and by the leptin receptor gene, which can produce six different isoforms: ObRa-f [66]. Leptin is known to play a key function in the hypothalamus. However, the ObR receptors are expressed also in various regions of the hippocampus, in particular at the level of the synapses, where they enhance the synaptic activity following interaction with leptin [67]. Leptin deficient obese mice show a significant impairment of the hippocampal synaptic plasticity, leading to a spatial memory impairment [68]. Leptin exerts a neuroprotective function. Leptin ablation in obese ob/ob mice results in a significant reduction of brain weight, which is ameliorated by leptin treatment [69]. Interestingly, diet is a risk factor for AD [70], suggesting a correlation between diet, metabolic dysfunction and AD. Furthermore, obesity and leptin resistance are risk factors for $\mathrm{AD}$. Leptin resistance leads to elevated leptin plasma levels. However, AD patients show weight loss and concomitant low leptin plasma level [71]. In addition, low circulating leptin is considered a risk for AD [72]. This contradiction results from the effect of leptin on the function of the hypothalamus. Thus, the ability of leptin to regulate food intake and body weight occurs within a tightly regulated concentration range, such that too low circulating leptin fails to maintain energy homeostasis, whereas elevated leptin levels present in the obese state produces leptin resistance and also leptin's incapacity in regulating food intake [73]. On the other hand, AD is characterized also by not cognitive alterations, such as late-life body weight loss and low body mass index (BMI) [74]. Interestingly, in AD patients as well as in elderly not affected by AD, weight loss and low BMI strongly correlate with AD pathological characteristics: increased amyloid burden [75] and CSF biomarkers of AD [76]. In addition, weight loss is predictive for the transition from amnestic mild cognitive impairment (aMCI) to AD [77]. These data strongly suggest a common mechanism between body metabolism alterations and AD. In agreement, metabolic dysfunction, changes in bodyweight ad altered feeding behavior are present not only in AD patients but also in the 3Tg AD mice model [78]. Moreover, the 5xFAD mice show gliosis associated to hypothalamus dysfunction, altered insulin and leptin signaling in the hypothalamus, which in turn affect the food intake, the energy expenditure, leading to diminished body weight [79].

It is relevant to note that metabolic alterations and weight loss in AD patients occur at least a decade before of the appearance of the first signs of cognitive impairment [80]. For this reason, the understanding of the molecular pathways promoting metabolic dysfunction in AD may provide the discovery of biomarkers essential for the early diagnosis of high risk to develop AD.

The observed metabolic dysfunction in AD may be due to alterations in hypothalamic activity. The hypothalamus is central for the modulation of the energy homeostasis and the feeding behavior. The hypothalamus coordinates the energy homeostasis by balancing the energy expenditure with the food intake. Such function is modulated also by peripheral molecules, such as insulin and leptin, but also of nutrients and their metabolites (e.g., glucose). Notably, the same pathways have a role in AD. Indeed, food intake -via leptinmediated hypothalamus activity- has a function in AD [81].

Notably, hypothalamic dysfunction occurs early in AD. Pathological features of AD, such as $\mathrm{A} \beta$ and tau, are found also in the hypothalamus [82]. Conversely, altered hypothalamic function due to $\mathrm{AD}$ is responsible of metabolic dysfunction. In agreement, $\mathrm{AD}$ seems to increase the risk to develop type 2 diabetes [83]. Moreover, $A \beta$ oligomers produced in $\mathrm{AD}$ alters the function of hypothalamic neurons, leading to peripheral metabolic dysfunction [84]. In turn, AD-induced metabolic dysfunction exerts an impact on the heart function. Thus, there is a bidirectional role of the metabolism in modulating the brain-heart axis in AD onset/progression and the hypothalamus plays a key role in this bi-directional regulation. 
Notably, TXNIP plays also a major role in modulating the response to nutrients and in the whole-body energy homeostasis. TXNIP is expressed in the nutrient-sensing neurons of the hypothalamus, where it responds to nutrients and hormonal signals and in turn regulates the adipose tissue metabolism [85]. TXNIP expressed in Agrp hypothalamic neurons regulates the leptin sensitivity of the central nervous system [86]. Considering the role of leptin in modulating the effect of metabolism on the brain-heart axis, we may speculate that TXNIP mediates the effect of metabolism in the brain-heart axis and may act early, before AD onset.

\section{The Renin-Angiotensin System: Role in AD and AD Risk Factors}

The renin-angiotensin system is essential for the regulation of vasoconstriction, blood pressure and cardiovascular homeostasis. Renin converts the angiotensinogen (AGT) into angiotensin I (ANGI), which in turn is converted to angiotensin II (ANGII) by the angiotensin converting enzyme 1 (ACE1). ANGII interacts with the angiotensin receptors (ATRs), modulating various signaling pathways that augment the blood pressure. Renin also induces the conversion of AGT to ANGII through activation of the pro-renin receptor (PRR), which enhances the activity of pro-renin. Short term activation of the renin-angiotensin system is beneficial. On the contrary, its prolonged activation affects the cardiovascular and renal systems, leading to fibrosis and hypertrophy [87]. Notably, there is a brain specific reninangiotensin system, whose components are expressed and produced in the brain: glial cells, and neurons, with an enhanced expression in the brain areas that are implicated in the modulation of the heart and fluid homeostasis [88]. Brain produces a particular isoform of renin: renin-b [89]. Research data are suggesting that the brain renin-angiotensin system modulates the systemic blood pressure. The knockout of AGT, PRR, or ATRs specifically into the brain blocks hypertension, while overexpression of genes enhancing ANGII production in the brain leads to hypertension in rodents [87]. ANG II produced in the brain by the brain renin exerts various neuronal effects, including the regulation of the sympathetic system and in turn may cooperate in causing the so-called neurogenic hypertension [90]. Thus, it plays a key role in the heart-brain axis. Moreover, patients affected by cardiovascular disease show enhanced activity of brain ACE and ACE inhibitors ameliorate cognitive decline in the elderly [88]. Noteworthy, TXNIP is implicated in ANGII-promoted cardiac fibrosis and hypertrophy and knockdown of TXNIP suppressed ANGII-induced cardiac remodeling [91]. These data further support the role of TXNIP in modulating the brain-heart axis.

Hypertension and diabetes are risk factors for cardiovascular disease and frequently occur together in patients [92]. Diabetes and hypertension are AD risk factor [4]. Interestingly, in diabetes several ANGII downstream effectors are altered, resulting in oxidative stress and inflammation. Notably, chronic ANGII activation produces oxidative stress, which in turn promotes insulin resistance and dyslipidemia, participating to diabetes. In addition, chronic ANGII activity may enhance sodium retention, contributing to hypertension [92]. In AD, the brain renin-angiotensin system causes activation of the microglia, leading to chronic inflammation, which in turn affects the neuronal function [93]. There is a bi-directional regulation between AD and the brain renin-angiotensin system. ANGII enhances the activity of the $\gamma-$ secretase, leading to an enhanced production of $A \beta$ [94]. Conversely, elevated $A \beta$ production promotes the oligomerization of $\mathrm{AT}_{2} \mathrm{R}$, which correlates with neurodegeneration [95].

Inhibitors of the renin-angiotensin system are proposed and studied as therapeutic strategy for AD [96]. However, the aim of the present review is the analysis of metabolic factors in the brain-heart axis and their role in AD. As described above, diabetes and hypertension show a bi-directional regulation with the renin-angiotensin system, affecting the heart-brain axis and in turn contributing to AD.

\section{The Natriuretic Peptides and Endothelins Counteract the Renin-Angiotensin Pathway: A Role in AD?}

The natriuretic peptides (NPs) are a family of hormones implicated in the homeostasis of fluid volume and blood pressure. They promote the excretion of sodium, counteracting the renin-angiotensin pathway [97]. NPs consist in 3 groups: atrial natriuretic peptide (ANP), brain natriuretic peptide (BNP), and C-type natriuretic peptide (CNP). NPs interact 
with three different receptors: (i) Natriuretic Receptor A (NPRA), which binds ANP and BNP; (ii) NPRB that interacts with CNP, and (iii) NPRC, which binds the three NPs groups [97]. NPs are expressed in cardiomyocytes during early development and their expression is activated also in the adult during cardiac remodeling due to stressors [97]. Both NPRA and NPRB are expressed in the brain, but NPRB is the most abundant NPs receptor in the brain [97]. All the NPs proteins are present in the brain. However, the mRNA encoding BNP is absent into the brain, showing that it is expressed in other tissues and then transported into the brain [97]. NPs have neuroprotective effects. Increased brain ANP reduces blood pressure [97]. On the contrary, intracerebroventricular delivery of CNP in sheep depresses blood pressure [97]. It has been shown a significant correlation between brain atrophy and brain BNP levels [98]. Since BNP is not expressed in the brain, these data are suggesting that cardiomyocytes produce BNP in response to brain injury. Interestingly, NPRA is more abundant in the brain of AD patients, while NPRB levels are reduced in the CSF of AD patients [99]. Notably, BNP and N-terminal pro-brain natriuretic peptide (NT-proBNP) are the most important humoral indicators of cardiac function and heart failure [100]. Recent studies are suggesting that natriuretic peptides play a role also in the regulation of the energy metabolism, creating a link between heart and insulin sensitive tissues [101]. It has been suggested that dysfunction of the natriuretic system participates to the development of type 2 diabetes and obesity [101], which are risk factors for AD.

Endothelins is a family of vasoactive peptides, including ET-1, ET-2 and ET-3, which play a relevant function in both cardiovascular functions and dysfunction [102]. ET-1 activates two different $\mathrm{G}$-coupled receptors: $\mathrm{ET}_{\mathrm{A}}$ and $\mathrm{ET}_{\mathrm{B}}$, with $\mathrm{ET}_{\mathrm{A}}$ mostly localized on vascular smooth muscle cells and pericytes and producing a contractile and proliferative effect following interaction with ET-1 [102]. On the contrary, ET $_{\mathrm{B}}$ expressed on endothelial cells leads to vasodilation. Only in pathological conditions ETB is expressed also on vascular smooth muscle cells promoting vasoconstriction [102]. Notably, ET-1 inhibits renin secretion from renal juxtaglomerular cells, modulating the renin-angiotensin system [103]. ET-1 induces cardiomyocytes hypertrophy by activating Protein Kinase C (PKC) [104]. ET-1 promotes cerebrovascular dysfunction by affecting the BBB, leading to BBB breakdown and subsequent inflammation [102]. Several studies indicate that ET-1 is implicated in cognitive impairment and AD by inducing vascular dysfunction [102]. ET-1 levels are increased in AD, leading to vascular dysfunction and inflammation. For this reason, ET-1 is considered a therapeutic target for AD [105]. In agreement, ET-1 interaction with $\mathrm{ET}_{\mathrm{A}}$ reduces the density and diameters of hippocampal capillaries in APP/PS1 mice, enhancing A $\beta$ deposition. Inhibitions of $\mathrm{ET}_{\mathrm{A}}$ with ferulic acid ameliorates microvascular dysfunction and A $\beta$ deposition [106]. Finally, it has been proposed a genetic linking between ET-1 and AD prevalence in certain populations that show enhanced ET-1 system, which may predispose to AD [107].

\section{Role of the Gut Microbiota in the Brain-Heart Axis: Effect of Metabolism}

All the microbes present within an ecological niche such as the gut constitute the microbiota, whereas the combination of a defined microbiota and their genes forms the microbiome [108]. The gut microbiota defines a complex ecosystem that includes microbes of all kingdoms (bacteria, fungi, archaea, protozoa, and the meiofauna). Notably, the microbiota establishes an intimate symbiotic relationship with the host [109].

The gut microbiome (GM) participates to the gut-brain axis both directly and indirectly. Several pathways constitute the gut-brain axis. Neural networks regulate the enteric nervous system independently or via the central nervous system (CNS), using the sympathetic efferent in prevertebral ganglia. Another pathway consists in parasympathetic efferent of the vagus nerve [110]. Through these pathways, the GM modulates the hypothalamic-pituitaryadrenal (HPA) axis and the brain function through microbial molecules and metabolites, which act as secondary messengers [111]. The enteric nervous system, which belongs to the autonomic nervous system, modulates the gastrointestinal function and cooperates with the vagal afferent nerves, which in turn transduce sensory information from the gut to the CNS [112]. Several studies underlined the bidirectional regulation in the gut-brain axis. 
Dysbiosis defines the alteration of the GM and is characterized by modifications of the composition of bacterial Phyla present in the gut [113]. Several recent studies underline its role in the development of metabolic diseases [114]. GM has an impact on the host health through two pathways: (i) the release of bacterial components, in particular pathogen-associated molecular patterns (PAMPs), which include lipopolysaccharides (LPS) as the most known component [115]: (ii) the production of metabolites derived from the processing of food in the gut. Notably, GM is essential in modulating the permeability of intestinal mucosa [116]. GM exerts a relevant impact on the host's metabolism. Dysbiosis is associated to altered metabolism and to diseases induced by metabolic dysregulation [117]. Dietary habits play a key role in promoting dysbiosis. The high-fat diet (HFD), which promotes the progression of metabolic syndrome (MS), obesity and type 2 diabetes, causes also dysbiosis. Such condition promotes an augmented permeability of the gut by the GM, leading to an increased LPS serum level, which stimulates inflammation and expansion of the adipose tissue [118], promoting the onset and progression of MS and type 2 diabetes, which are risk factors of $\mathrm{AD}$ and of cardiovascular diseases. Moreover, dysbiosis strongly affects the integrity of the BBB, leading to neuroinflammation [119]. As we described before, neuroinflammation affects the CAN. Western diet induces inflammation of the hypothalamus, which in turn promotes leptin resistance and weight gain [120]. Notably, depletion of the GM in mice fed with HFD results in a diminished inflammation of the hypothalamus and improves leptin sensitivity [120]. Interestingly, GM depleted mice fed with HFD show enhanced levels of glucagon-like peptide 1 (GLP-1), which is essential for GM depletion-induced amelioration of hypothalamus inflammation [120] through the signaling downstream GLP-1 receptor (GLP-1R) present on astrocytes [120]. These data further demonstrate the role of GM in modulating the function of the hypothalamus and the downstream regulatory cascade.

In particular, it has been described a bidirectional regulation between the GM and the CAN [110]. The gut-brain axis is mediated by the vagus nerve [110]. The afferent fibers of the vagus nerve act as a sensor for the metabolites released by the GM and transduce the alterations of the GM metabolites to the brain. Conversely, the vagus nerve can modify the GM composition by the cholinergic efferents, which release an anti-inflammatory signal. In agreement, diminished vagal tone leads to dysbiosis [110]. Furthermore, enhanced sympathetic activity is correlated to dysbiosis, increased gut permeability and inflammation [121]. Moreover, GM and sympathetic alterations promote high blood pressure in an animal model of hypertension [122]. In this animal model, reduction of the sympathetic activity, using acethylcoline esterase inhibitors, reduces the blood pressure, ameliorates the dysbiosis and gut permeability [122]. In addition, dysbiosis leads to autonomic imbalance and activates the sympathetic system, promoting inflammation [123]. Interestingly, dysbiosis affects also the renin-angiotensin system, promoting vascular dysfunction through angiotensin II [124]. Thus, dysbiosis affects also the cardiovascular system via a GM-dependent gut-brain-heart axis. Notably, activation of the angiotensin converting enzyme 2 can diminish the immune response by altering the GM, suggesting that alterations of the renin-angiotensin system due to MS and type 2 diabetes promote inflammation by altering the GM [125].

During the course of aging, the gastrointestinal tract epithelial barrier and the BBB become significantly more permeable [126]. Thus, the CNS becomes more susceptible to potential neurotoxins generated by the GM. Microbial insults contribute to AD, by promoting a pathological cascade throughout the vagus nerves to the CNS. Moreover, GM can be affected by other pathological agents, such as fungal or viral infections. Such altered GM may contribute to AD [111]. AD patients show chronic fungal infections and disseminated diffuse mycoses, further confirming that altered microbiome contribute to AD [127]. Altered GM can prime the immune system, which in turn become activated by the brain $\mathrm{A} \beta$ [128]. Exposure to Manganese $(\mathrm{Mn})$ can promote AD progression by inducing neuroinflammation. Notably, the transplantation of fecal microbiome derived from control rats to rats exposed to $\mathrm{Mn}$ reduces neuroinflammation and $\mathrm{A} \beta$ production, confirming the role of MG in AD pathophysiology and the therapeutical role of MG remodeling [129]. Similarly, 
fecal microbiota transfer from wild type mice to AD mice alleviates AD hallmarks [130]. The modulation of the GM composition exerts a relevant role in modulating the activity of the microglia and its A $\beta$ clearance capability [131]. Interestingly, the transplantation of GM from human AD patients to wild type mice results in gut inflammatory response [132]. $\mathrm{AD}$ patients show $\mathrm{A} \beta$ deposition also in the intestine [133].

Thus, GM participates in the regulation of the brain-heart axis by acting on several pathways modulating the ANS (Figure 1). GM and metabolic pathways also show a bidirectional mutual regulation, which in turn has an impact on the heart-brain axis and also contributes to $\mathrm{AD}$.

\section{Conclusions}

The studies summarized above underline the bidirectional regulation between brain and heart as well as the key impact of metabolism in modulating the brain-heart axis. Notably, metabolic alterations have an effect on the brain-heart axis and participate to AD progression. Recent studies unveil the key role of metabolism in driving the early phases of $\mathrm{AD}$. In addition, the study of the effect of metabolism in altering the brain-heart axis is providing new biomarkers for the early diagnosis of AD, such as ADMA and TXNIP. Moreover, recent evidences suggest that the analysis of TXNIP function may provide new therapeutic strategies for AD. The role of TXNIP in the progression of cardiovascular dysfunction as well as in the regulation of metabolism is well known, while the study of TXNIP implication in AD is more recent. Considering the role of TXNIP in mediating the whole-body response to metabolic alterations, the fact that TXNIP is a marker of cardiovascular diseases and is implicated also in AD, we may speculate that TXNIP has a key role in the brain-heart axis, and it may be implicated in driving the effect of metabolic alterations in brain-heart axis, which ultimately promote AD (Figure 2).

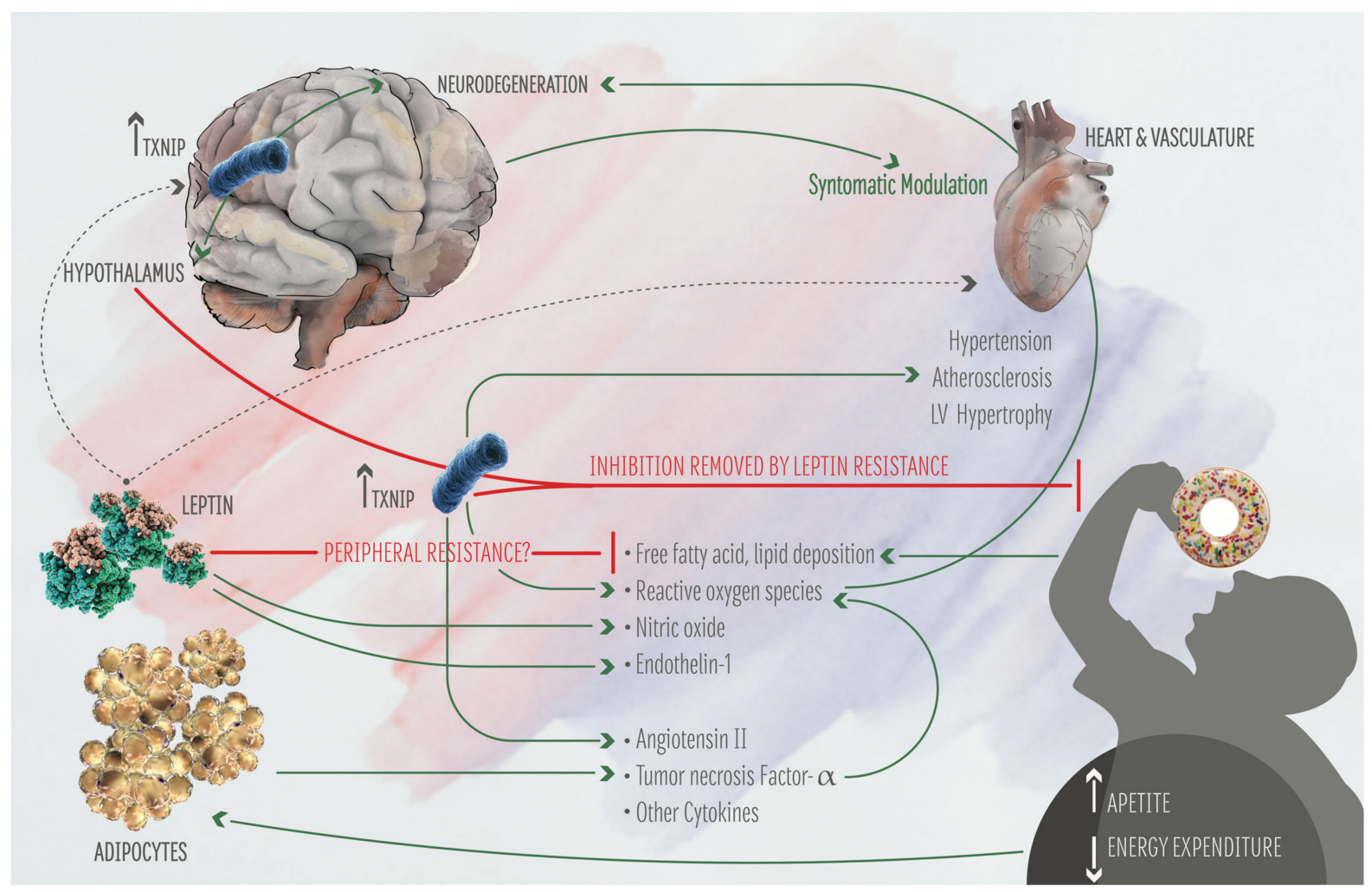

Figure 2. Effect of TXNIP on the brain-heart axis and on human metabolism. Food intake increases TXNIP expression in Agrp neurons of the hypothalamus, inducing satiety. Enhanced expression of TXNIP in the hippocampus leads to neuronal dysfunction. Hyperglycemia and diabetes induce elevated TXNIP expression in several tissues, leading to hypertension, atherosclerosis, and enhanced production of reactive oxygen species (ROS). In turn, ROS participate to neurodegeneration. It is also shown the effect of Leptin on the metabolism and the brain-heart axis. 
Further studies are important to consolidate the hypothesis that TXNIP drives the effect of metabolism in altering the brain-heart axis, leading a cascade of effects that in turn promote AD.

Author Contributions: L.P.: conceptualization and writing the manuscript. M.V.: participation in writing the manuscript. All authors have read and agreed to the published version of the manuscript.

Funding: This research received no external funding.

Acknowledgments: We thank Antonia Auletta for graphical help for the figures, the Gian Luigi Gigli for reading the manuscript and for the helpful suggestions.

Conflicts of Interest: The authors declare no conflict of interest.

\begin{tabular}{|c|c|}
\hline Abbreviations & \\
\hline $\mathrm{AD}$ & Alzheimer Disease \\
\hline TXNIP & Thioredoxin Interacting protein \\
\hline$A \beta$ & amyloid beta \\
\hline APP & amyloid precursor protein \\
\hline PSEN1 and PSEN2 & presenilin 1 and 2 \\
\hline LOAD & late onset Alzheimer Disease \\
\hline FAD & familiar Alzheimer Disease \\
\hline NMDA & N-methyl-D-aspartate \\
\hline ChEIs & inhibitors of the cholinesterase \\
\hline ADMA & Asymmentric DiMethyl Arginine \\
\hline SVD & small vessels disease \\
\hline RAGE & Receptor for Advanced Glycation Endproducts \\
\hline BBB & Blood Brain Barrier \\
\hline $\operatorname{Tr} x$ & Thioredoxin \\
\hline ROS & reactive oxygen species \\
\hline TBP-2 & Thioredoxin Binding protein 2 \\
\hline VDUP-1 & Vitamin D Upregulated Protein 1 \\
\hline AGEs & Advanced Glycation Endproducts \\
\hline HMGB1 & high mobiliy group B1 \\
\hline NLRP3 & NOD-like receptor family, pyrin domain containing 3 \\
\hline PD & Parkinson Disease \\
\hline HRV & heart rate variability \\
\hline ApoE4 & apolipoprotein E4 \\
\hline CAN & central autonomic network \\
\hline ANS & autonomic nervous system \\
\hline aMCI & amnestic mild cognitive impairment \\
\hline HR & heart rate \\
\hline$o b$ & obese gene \\
\hline $\mathrm{db}$ & diabetes gene \\
\hline ObR & leptin receptor \\
\hline BMI & body mass index \\
\hline AGT & angiotensinogen \\
\hline ANGII & angiotensin II \\
\hline ACE1 & angiotensin converting enzyme 1 \\
\hline ATRs & angiotensin receptors \\
\hline PRR & pro-renin receptor \\
\hline NPs & natriuretic peptides \\
\hline ANP & atrial natriuretic peptide \\
\hline $\mathrm{BNP}$ & brain natriuretic peptide \\
\hline $\mathrm{CNP}$ & C-type natriuretic peptide \\
\hline NPRA & Natriuretic Receptor A \\
\hline NPRB & Natriuretic Receptor B \\
\hline NPRC & Natriuretic Receptor C \\
\hline NT-proBNP & N-terminal pro-brain natriuretic peptide \\
\hline ET-1, 2, 3 & Endothelin 1, 2, 3 \\
\hline
\end{tabular}




$\begin{array}{ll}\text { PKC } & \text { Protein Kinase C } \\ \text { CNS } & \text { central nervous system } \\ \text { GM } & \text { gut microbiome } \\ \text { PAMPs } & \text { pathogen-associated molecular patterns } \\ \text { LPS } & \text { lipopolysaccharides } \\ \text { HFD } & \text { high-fat diet } \\ \text { MS } & \text { metabolic syndrome } \\ \text { GLP-1 } & \text { glucagon-like peptide 1 } \\ \text { GLP-1R } & \text { GLP-1 receptor }\end{array}$

\section{References}

1. Prince, M.; Ali, G.C.; Guerchet, M.; Prina, A.M.; Albanese, E.; Wu, Y.T. Recent global trends in the prevalence and incidence of dementia, and survival with dementia. Alzheimers Res. Ther. 2016, 8, 23. [CrossRef] [PubMed]

2. Querfurth, H.W.; LaFerla, F.M. Alzheimer's disease. N. Engl. J. Med. 2010, 362, 329-344. [CrossRef] [PubMed]

3. Pimenova, A.A.; Raj, T.; Goate, A.M. Untangling Genetic Risk for Alzheimer's Disease. Biol. Psychiatry 2018, 83, 300-310. [CrossRef]

4. Perrone, L.; Sbai, O.; Nawroth, P.P.; Bierhaus, A. The Complexity of Sporadic Alzheimer's Disease Pathogenesis: The Role of RAGE as Therapeutic Target to Promote Neuroprotection by Inhibiting Neurovascular Dysfunction. Int. J. Alzheimers Dis. 2012, 2012, 734956-734966. [CrossRef]

5. Steinbrook, R. The Accelerated Approval of Aducanumab for Treatment of Patients with Alzheimer Disease. JAMA Intern. Med. 2021, 181, 1281. [CrossRef]

6. Crosson, F.J.; Covinsky, K.; Redberg, R.F. Medicare and the Shocking US Food and Drug Administration Approval of Aducanumab: Crisis or Opportunity? JAMA Intern. Med. 2021, 181, 1278-1280. [CrossRef] [PubMed]

7. Liu, G.; Yao, L.; Liu, J.; Jiang, Y.; Ma, G.; Chen, Z.; Zhao, B.; Li, K.; (GERAD1) Consortium. Cardiovascular disease contributes to Alzheimer's disease: Evidence from large-scale genome-wide association studies. Neurobiol. Aging 2014, 35, 786-792. [CrossRef]

8. Ungvari, Z.; Toth, P.; Tarantini, S.; Prodan, C.I.; Sorond, F.; Merkely, B.; Csiszar, A. Hypertension-induced cognitive impairment: From pathophysiology to public health. Nat. Rev. Nephrol. 2021, 14, 1-16.

9. Lee, H.J.; Seo, H.I.; Cha, H.Y.; Yang, Y.J.; Kwon, S.H.; Yang, S.J. Diabetes and Alzheimer's Disease: Mechanisms and Nutritional Aspects. Clin. Nutr. Res. 2018, 7, 229-240. [CrossRef]

10. Gómez-Apo, E.; Mondragón-Maya, A.; Ferrari-Díaz, M.; Silva-Pereyra, J. Structural Brain Changes Associated with Overweight and Obesity. J. Obes. 2021, 2021, 6613385. [CrossRef]

11. Wanamaker, B.L.; Swiger, K.J.; Blumenthal, R.S.; Martin, S.S. Cholesterol, statins, and dementia: What the cardiologist should know. Clin. Cardiol. 2015, 38, 243-250. [CrossRef]

12. Janes, F.; Cifù, A.; Pessa, M.E.; Domenis, R.; Gigli, G.L.; Sanvilli, N.; Nilo, A.; Garbo, R.; Curcio, F.; Giacomello, R.; et al. ADMA as a possible marker of endothelial damage. A study in young asymptomatic patients with cerebral small vessel disease. Sci. Rep. 2019, 9, 14207. [CrossRef] [PubMed]

13. Arlt, S.; Schulze, F.; Eichenlaub, M.; Maas, R.; Lehmbeck, J.T.; Schwedhelm, E.; Jahn, H.; Böger, R.H. Asymmetrical dimethylarginine is increased in plasma and decreased in cerebrospinal fluid of patients with Alzheimer's disease. Dement. Geriatr. Cogn. Disord. 2008, 26, 58-64. [CrossRef] [PubMed]

14. Malden, D.E.; Mangoni, A.A.; Woodman, R.J.; Thies, F.; McNeil, C.; Murray, A.D.; Soiza, R.L. Circulating asymmetric dimethylarginine and cognitive decline: A 4-year follow-up study of the 1936 Aberdeen Birth Cohort. Int. J. Geriatr. Psychiatry 2020, 35, 1181-1188. [CrossRef] [PubMed]

15. Bu, X.L.; Xiang, Y.; Jin, W.S.; Wang, J.; Shen, L.L.; Huang, Z.L.; Zhang, K.; Liu, Y.H.; Zeng, F.; Liu, J.H.; et al. Blood-derived amyloid-beta protein induces Alzheimer's disease pathologies. Mol. Psychiatry 2018, 23, 1948-1956. [CrossRef] [PubMed]

16. Tublin, J.M.; Adelstein, J.M.; Del Monte, F.; Combs, C.K.; Wold, L.E. Getting to the Heart of Alzheimer Disease. Circ. Res. 2019, 124, 142-149. [CrossRef] [PubMed]

17. Troncone, L.; Luciani, M.; Coggins, M.; Wilker, E.H.; Ho, C.Y.; Codispoti, K.E.; Frosch, M.P.; Kayed, R.; Del Monte, F. Abeta Amyloid Pathology Affects the Hearts of Patients With Alzheimer's Disease: Mind the Heart. J. Am. Coll. Cardiol. 2016, 68, 2395-2407. [CrossRef] [PubMed]

18. Xu, C.; Tao, X.; Ma, X.; Zhao, R.; Cao, Z. Cognitive Dysfunction after Heart Disease: A Manifestation of the Heart-Brain Axis. Oxid. Med. Cell. Longev. 2021, 2021, 4899688. [CrossRef] [PubMed]

19. Qayyum, N.; Haseeb, M.; Kim, M.S.; Choi, S. Role of Thioredoxin-Interacting Protein in Diseases and Its Therapeutic Outlook. Int. J. Mol. Sci. 2021, 22, 2754. [CrossRef]

20. Kim, S.Y.; Suh, H.W.; Chung, J.W.; Yoon, S.R.; Choi, I. Diverse functions of VDUP1 in cell proliferation, differentiation, and diseases. Cell. Mol. Immunol. 2007, 4, 345-351. [PubMed]

21. Perrone, L.; Devi, T.S.; Hosoya, K.C.; Terasaki, T.; Singh, L.P. Thioredoxin Interacting Protein (TXNIP) induces inflammation through chromatin modification in retinal capillary endothelial cells under diabetic conditions. J. Cell. Physiol. 2009, 221, 262-272. [CrossRef] [PubMed] 
22. Perrone, L.; Devi, T.S.; Hosoya, K.C.; Terasaki, T.; Singh, L.P. Inhibition of TXNIP Expression In Vivo Blocks Early Pathologies of Diabetic Retinopathy. Cell Death Dis. 2010, 1, e65. [CrossRef] [PubMed]

23. Domingues, A.; Jolibois, J.; Marquet de Rougé, P.; Nivet-Antoine, V. The Emerging Role of TXNIP in Ischemic and Cardiovascular Diseases; A Novel Marker and Therapeutic Target. Int. J. Mol. Sci. 2021, 22, 1693. [CrossRef] [PubMed]

24. Zhou, R.; Tardivel, A.; Thorens, B.; Choi, I.; Tschopp, J. Thioredoxin-interacting protein links oxidative stress to inflammasome activation. Nat. Immunol. 2010, 11, 136-140. [CrossRef] [PubMed]

25. Sbai, O.; Devi, T.S.; Melone, M.A.B.; Feron, F.; Khrestchatisky, M.; Singh, L.P.; Perrone, L. RAGE-TXNIP axis is required for S100Bpromoted Schwann cell migration, fibronectin expression and cytokine secretion. J. Cell Sci. 2010, 123, 4332-4339. [CrossRef] [PubMed]

26. Tsubaki, H.; Tooyama, I.; Walker, D.G. Thioredoxin-Interacting Protein (TXNIP) with Focus on Brain and Neurodegenerative Diseases. Int. J. Mol. Sci. 2020, 21, 9357. [CrossRef]

27. Wang, Y.; Wang, Y.; Bharti, V.; Zhou, H.; Hoi, V.; Tan, H.; Wu, Z.; Nagakannan, P.; Eftekharpour, E.; Wang, J.F. Upregulation of Thioredoxin-Interacting Protein in Brain of Amyloid- $\beta$ Protein Precursor/Presenilin 1 Transgenic Mice and Amyloid- $\beta$ Treated Neuronal Cells. J. Alzheimers Dis. 2019, 72, 139-150. [CrossRef] [PubMed]

28. Hokama, M.; Oka, S.; Leon, J.; Ninomiya, T.; Honda, H.; Sasaki, K.; Iwaki, T.; Ohara, T.; Sasaki, T.; LaFerla, F.M.; et al. Altered Expression of Diabetes-Related Genes in Alzheimer's Disease Brains: The Hisayama Study. Cereb. Cortex. 2014, 24, $2476-2488$. [CrossRef]

29. Melone, M.A.B.; Dato, C.; Paladino, S.; Coppola, C.; Trebini, C.; Giordana, M.; Perrone, L. Verapamil Inhibits Ser202/Thr205 Phosphorylation of Tau by Blocking TXNIP/ROS/p38 MAPK Pathway. Pharm. Res. 2018, 35, 44. [CrossRef]

30. Matrone, C.; Djelloul, M.; Taglialatela, G.; Perrone, L. Inflammatory risk factors and pathologies promoting Alzheimer's disease progression: Is RAGE the key? Histol. Histopathol. 2015, 30, 125-139.

31. Abate, G.; Uberti, D.L.; Djelloul, M.; Sbai, O.; Ieraci, A.; Perrone, L. RAGE-TXNIP axis drives inflammation in Alzheimer's by targeting $\mathrm{A} \beta$ to mitochondria in microglia. Preprint 2020. [CrossRef]

32. Li, D.; Parks, S.B.; Kushner, J.D.; Nauman, D.; Burgess, D.; Ludwigsen, S.; Partain, J.; Nixon, R.R.; Allen, C.N.; Irwin, R.P.; et al. Mutations of presenilin genes in dilated cardiomyopathy and heart failure. Am. J. Hum. Genet. 2006, 79, 1030-1039. [CrossRef] [PubMed]

33. Chen, W.; Jin, F.; Cao, G.; Mei, R.; Wang, Y.; Long, P.; Wang, X.; Ge, W. ApoE4 May be a Promising Target for Treatment of Coronary Heart Disease and Alzheimer's Disease. Curr. Drug Targets 2018, 19, 1038-1044. [CrossRef] [PubMed]

34. Richard, M.A.; Huan, T.; Ligthart, S.; Gondalia, R.; Jhun, M.A.; Brody, J.A.; Irvin, M.R.; Marioni, R.; Shen, J.; Tsai, P.C.; et al. DNA Methylation Analysis Identifies Loci for Blood Pressure Regulation. Am. J. Hum. Genet. 2017, 101, 888-902. [CrossRef] [PubMed]

35. Zhang, Y.; Huang, J.; Yang, X.; Sun, X.; Xu, Q.; Wang, B.; Zhong, P.; Wei, Z. Altered Expression of TXNIP in the peripheral leukocytes of patients with coronary atherosclerotic heart disease. Medicine 2017, 96, e9108. [CrossRef] [PubMed]

36. Palma, J.A.; Benarroch, E.E. Neural control of the heart. Recent concepts and clinical correlations. Neurology 2014, 8, 261-271. [CrossRef] [PubMed]

37. Van der Wall, E.E.; van Gilst, W.H. Neurocardiology: Close interaction between heart and brain. Neth. Heart J. 2013, 21, 51-52. [CrossRef] [PubMed]

38. Thayer, J.F.; Hansen, A.L.; Saus-Rose, E.; Johnsen, B.H. Heart rate variability, prefrontal neural function, and cognitive performance: The neurovisceral integration perspective on self-regulation, adaptation, and health. Ann. Behav. Med. 2009, 37, 141-153. [CrossRef]

39. Tahsili-Fahadan, P.; Geocadin, R.G. Heart-brain axis: Effects of neurologic injury on cardiovascular function. Circ. Res. 2017, 120, 559-572. [CrossRef] [PubMed]

40. Nicolini, P.; Ciulla, M.M.; De Asmundis, C.; Magrini, F.; Brugada, P. The prognostic value of heart rate variability in the elderly, changing the perspective: From sympathovagal balance to chaos theory. Pacing Clin. Electrophysiol. 2012, 35, 622-638. [CrossRef]

41. Al Hazzouri, A.Z.; Haan, M.N.; Deng, Y.; Neuhaus, J.; Yaffe, K. Reduced heart rate variability is associated with worse cognitive performance in elderly Mexican Americans. Hypertension 2014, 63, 181-187. [CrossRef]

42. Da Silva, V.P.; Ramalho Oliveira, B.R.; Tavares Mello, R.G.; Moraes, H.; Deslandes, A.C.; Laks, J. Heart Rate Variability Indexes in Dementia: A Systematic Review with a Quantitative Analysis. Curr. Alzheimer Res. 2018, 15, 80-88. [CrossRef]

43. Chen, J.; Zhang, Z.; Li, S. Can multi-modal neuroimaging evidence from hippocampus provide biomarkers for the progression of amnestic mild cognitive impairment? Neurosci. Bull. 2015, 31, 128-140. [CrossRef] [PubMed]

44. Bayram, E.; Caldwell, J.Z.K.; Banks, S.J. Current understanding of magnetic resonance imaging biomarkers and memory in Alzheimer's disease. Alzheimers Dement. 2018, 4, 395-413. [CrossRef] [PubMed]

45. Ruggiero, D.A.; Mraovitch, S.; Granata, A.R.; Anwar, M.; Reis, D.J. A role of insular cortex in cardiovascular function. J. Comp. Neurol. 1987, 257, 189-207. [CrossRef] [PubMed]

46. Allen, B.; Jennings, J.R.; Gianaros, P.J.; Thayer, J.F.; Manuck, S.B. Resting high-frequency heart rate variability is related to resting brain perfusion. Psychophysiology 2015, 52, 277-287. [CrossRef] [PubMed]

47. Kimmerly, D.S. A review of human neuroimaging investigations involved with central autonomic regulation of baroreflexmediated cardiovascular control. Auton. Neurosci. 2017, 207, 10-21. [CrossRef] 
48. Valenza, G.; Passamonti, L.; Duggento, A.; Toschi, N.; Barbieri, R. Uncovering complex central autonomic networks at rest: A functional magnetic resonance imaging study on complex cardiovascular oscillations. J. R. Soc. Interface 2020, 17, 20190878. [CrossRef]

49. Frontoni, S.; Bracaglia, D.; Gigli, F. Relationship between autonomic dysfunction, insulin resistance and hypertension, in diabetes. Nutr. Metab. Cardiovasc. Dis. 2005, 15, 441-449. [CrossRef] [PubMed]

50. Enriori, P.J.; Sinnayah, P.; Simonds, S.E.; Garcia Rudaz, C.; Cowley, M.A. Leptin action in the dorsomedial hypothalamus increases sympathetic tone to brown adipose tissue in spite of systemic leptin resistance. J. Neurosci. 2011, 31, 12189-12197. [CrossRef]

51. Guarino, D.; Nannipieri, M.; Iervasi, G.; Taddei, S.; Bruno, R.M. The Role of the Autonomic Nervous System in the Pathophysiology of Obesity. Front. Physiol. 2017, 8, 665. [CrossRef]

52. Landsberg, L. Insulin-mediated sympathetic stimulation: Role in the pathogenesis of obesity-related hypertension (or, how insulin affects blood pressure, and why). J. Hypertens. 2001, 19, 523-528. [CrossRef]

53. Battault, S.; Meziat, C.; Nascimento, A.; Braud, L.; Gayrard, S.; Legros, C.; De Nardi, F.; Drai, J.; Cazorla, O.; Thireau, J.; et al. Vascular endothelial function masks increased sympathetic vasopressor activity in rats with metabolic syndrome. Am. J. Physiol. Heart Circ. Physiol. 2018, 314, H497-H507. [CrossRef] [PubMed]

54. Ferreira, N.E.; Omae, S.; Pereira, A.; Rodrigues, M.V.; Miyakawa, A.A.; Campos, L.C.; Santos, P.C.; Dallan, L.A.; Martinez, T.L.; Santos, R.D.; et al. Thioredoxin interacting protein genetic variation is associated with diabetes and hypertension in the Brazilian general population. Atherosclerosis 2012, 221, 131-136. [CrossRef] [PubMed]

55. Alvim, R.O.; Santos, P.C.; Ferreira, N.E.; Mill, J.G.; Krieger, J.E.; Pereira, A.C. Thioredoxin interacting protein (TXNIP) rs7212 polymorphism is associated with arterial stiffness in the Brazilian general population. J. Hum. Hypertens. 2012, 26, 340-342. [CrossRef]

56. Wang, X.B.; Han, Y.D.; Zhang, S.; Cui, N.H.; Liu, Z.J.; Huang, Z.L.; Li, C.; Zheng, F. Associations of polymorphisms in TXNIP and gene-environment interactions with the risk of coronary artery disease in a Chinese Han population. J. Cell Mol. Med. 2016, 20, 2362-2373. [CrossRef]

57. Yoshihara, E. TXNIP/TBP-2, A Master Regulator for Glucose Homeostasis. Antioxidants 2020, 9, 765. [CrossRef]

58. Wu, N.; Zheng, B.; Shaywitz, A.; Dagon, Y.; Tower, C.; Bellinger, G.; Shen, C.H.; Wen, J.; Asara, J.; McGraw, T.E.; et al. AMPKDependent Degradation of TXNIP upon Energy Stress Leads to Enhanced Glucose Uptake via GLUT1. Mol. Cell. 2013, 49, 1167-1175. [CrossRef]

59. Waldhart, A.N.; Dykstra, H.; Peck, A.S.; Boguslawski, E.A.; Madaj, Z.B.; Wen, J.; Veldkamp, K.; Hollowell, M.; Zheng, B.; Cantley, L.C.; et al. Phosphorylation of TXNIP by AKT Mediates Acute Influx of Glucose in Response to Insulin. Cell Rep. 2017, 19, 2005-2013. [CrossRef] [PubMed]

60. Pandit, R.; Beerens, S.; Adan, R.A.H. Role of leptin in energy expenditure: The hypothalamic perspective. Am. J. Physiol. Regul. Integr. Comp. Physiol. 2017, 312, R938-R947. [CrossRef]

61. Elmquist, J.K.; Elias, C.F.; Saper, C.B. From lesions to leptin: Hypothalamic control of food intake and body weight. Neuron 1999, 22, 221-232. [CrossRef]

62. Bell, B.B.; Rahmouni, K. Leptin as a Mediator of Obesity-Induced Hypertension. Curr. Obes. Rep. 2016, 5, 397-404. [CrossRef] [PubMed]

63. Da Silva, A.A.; do Carmo, J.M.; Hall, J.E. CNS Regulation of Glucose Homeostasis: Role of the Leptin-Melanocortin System. Curr. Diab. Rep. 2020, 26, 29. [CrossRef] [PubMed]

64. Gruber, T.; Pan, C.; Contreras, R.E.; Wiedemann, T.; Morgan, D.A.; Skowronski, A.A.; Lefort, S.; Murat, C.D.; Le Thuc, O.; Legutko, B.; et al. Obesity-associated hyperleptinemia alters the gliovascular interface of the hypothalamus to promote hypertension. Cell Metab. 2021, 33, 1155-1170. [CrossRef] [PubMed]

65. Meakin, P.J.; Jalicy, S.M.; Montagut, G.; Allsop, D.J.P.; Cavellini, D.L.; Irvine, S.W.; McGinley, C.; Liddell, M.K.; McNeilly, A.D.; Parmionova, K.; et al. Bace1-dependent amyloid processing regulates hypothalamic leptin sensitivity in obese mice. Sci. Rep. 2018, 8, 55. [CrossRef] [PubMed]

66. Farooqi, I.S.; O'Rahilly, S. 20 years of leptin: Human disorders of leptin action. J. Endocrinol. 2014, 223, T63-T70. [CrossRef]

67. Shanley, L.J.; Irving, A.J.; Harvey, J. Leptin enhances NMDA receptor function and modulates hippocampal synaptic plasticity. J. Neurosci. 2001, 21, RC186. [CrossRef] [PubMed]

68. Li, X.L.; Aou, S.; Oomura, Y.; Hori, N.; Fukunaga, K.; Hori, T. Impairment of long-term potentiation and spatial memory in leptin receptor-deficient rodents. Neuroscience 2002, 113, 607-615. [CrossRef]

69. Ahima, R.S.; Bjorbaek, C.; Osei, S.; Flier, J.S. Regulation of neuronal and glial proteins by leptin: Implications for brain development. Endocrinology 1999, 140, 2755-2762. [CrossRef]

70. Perrone, L.; Grant, W.B. Observational and ecological studies of dietary advanced glycation end products in national diets and Alzheimer's disease incidence and prevalence. J. Alzheimers Dis. 2015, 45, 965-979. [CrossRef]

71. Power, D.A.; Noel, J.; Collins, R.; O'Neill, D. Circulating leptin levels and weight loss in Alzheimer's disease patients. Dement. Geriatr. Cogn. Disord. 2001, 12, 167-170. [CrossRef] [PubMed]

72. Lieb, W.; Beiser, A.S.; Vasan, R.S.; Tan, Z.S.; Au, R.; Harris, T.B.; Roubenoff, R.; Auerbach, S.; DeCarli, C.; Wolf, P.A.; et al. Association of plasma leptin levels with incident Alzheimer disease and MRI measures of brain aging. JAMA 2009, 302, $2565-2572$. [CrossRef] [PubMed]

73. Friedman, J. 20 years of leptin: Leptin at 20, An overview. J. Endocrinol. 2014, 223, T1-T8. [CrossRef] [PubMed] 
74. Guérin, O.; Andrieu, S.; Schneider, S.M.; Cortes, F.; Cantet, C.; Gillette-Guyonnet, S.; Vellas, B. Characteristics of Alzheimer's disease patients with a rapid weight loss during a six-year follow-up. Clin. Nutr. 2009, 28, 141-146. [CrossRef] [PubMed]

75. Rabin, J.S.; Shirzadi, Z.; Swardfager, W.; MacIntosh, B.J.; Schultz, A.; Yang, H.S.; Buckley, R.F.; Gatchel, J.R.; Kirn, D.; Pruzin, J.J.; et al. Amyloid-beta burden predicts prospective decline in body mass index in clinically normal adults. Neurobiol. Aging 2020, 93, 124-130. [CrossRef] [PubMed]

76. Ewers, M.; Schmitz, S.; Hansson, O.; Walsh, C.; Fitzpatrick, A.; Bennett, D.; Minthon, L.; Trojanowski, J.Q.; Shaw, L.M.; Faluyi, Y.O.; et al. Body mass index is associated with biological CSF markers of core brain pathology of Alzheimer's disease. Neurobiol. Aging 2012, 33, 1599-1608. [CrossRef]

77. Cova, I.; Clerici, F.; Rossi, A.; Cucumo, V.; Ghiretti, R.; Maggiore, L.; Pomati, S.; Galimberti, D.; Scarpini, E.; Mariani, C.; et al. Weight Loss Predicts Progression of Mild Cognitive Impairment to Alzheimer's Disease. PLoS ONE 2016, 11, e0151710. [CrossRef]

78. Robison, L.S.; Gannon, O.J.; Thomas, M.A.; Salinero, A.E.; Abi-Ghanem, C.; Poitelon, Y.; Belin, S.; Zuloaga, K.L. Role of sex and high-fat diet in metabolic and hypothalamic disturbances in the 3xTg-AD mouse model of Alzheimer's disease. J. Neuroinflamm. 2020, 17, 285. [CrossRef]

79. López-Gambero, A.J.; Rosell-Valle, C.; Medina-Vera, D.; Navarro, J.A.; Vargas, A.; Rivera, P.; Sanjuan, C.; Rodríguez de Fonseca, F.; Suárez, J. A Negative Energy Balance Is Associated with Metabolic Dysfunctions in the Hypothalamus of a Humanized Preclinical Model of Alzheimer's Disease, the 5XFAD Mouse. Int. J. Mol. Sci. 2021, 22, 5365. [CrossRef]

80. Johnson, D.K.; Wilkins, C.H.; Morris, J.C. Accelerated weight loss may precede diagnosis in Alzheimer disease. Arch. Neurol. 2006, 63, 1312-1317. [CrossRef]

81. McGregor, G.; Harvey, J. Food for thought: Leptin regulation of hippocampal function and its role in Alzheimer's disease. Neuropharmacology. Neuropharmacology 2018, 136, 298-306. [CrossRef]

82. Ishii, M.; Iadecola, C. Metabolic and non-cognitive manifestations of Alzheimer's disease: The hypothalamus as both culprit and target of pathology. Cell Metab. 2015, 22, 761-776. [CrossRef] [PubMed]

83. Janson, J.; Laedtke, T.; Parisi, J.E.; O’Brien, P.; Petersen, R.C.; Butler, P.C. Increased risk of type 2 diabetes in Alzheimer disease. Diabetes 2004, 53, 474-481. [CrossRef] [PubMed]

84. Clarke, J.R.; Lyra, E.; Silva, N.M.; Figueiredo, C.P.; Frozza, R.L.; Ledo, J.H.; Katashima, C.K.; Razolli, D.; Carvalho, B.; Frazao, R.; et al. Alzheimer-associated $\mathrm{A} \beta$ oligomers impact the central nervous system to induce peripheral metabolic deregulation. $E M B O$ Mol. Med. 2015, 7, 190-210. [CrossRef]

85. Blouet, C.; Schwartz, G.J. Nutrient-sensing hypothalamic TXNIP links nutrient excess to energy imbalance in mice. J. Neurosci. 2011, 31, 6019-6027. [CrossRef] [PubMed]

86. Blouet, C.; Liu, S.M.; Jo, Y.H.; Chua, S.; Schwartz, G.J. TXNIP in Agrp neurons regulates adiposity, energy expenditure, and central leptin sensitivity. J. Neurosci. 2012, 32, 9870-9877. [CrossRef] [PubMed]

87. Mehta, P.K.; Griendling, K.K. Angiotensin II cell signaling: Physiological and pathological effects in the cardiovascular system. Am. J. Physiol. Cell Physiol. 2007, 292, C82-C97. [CrossRef] [PubMed]

88. Nakagawa, P.; Sigmund, C.D. How Is the Brain Renin-Angiotensin System Regulated? Hypertension 2017, 70, 10-18. [CrossRef]

89. Sinn, P.L.; Sigmund, C.D. Identification of three human renin mRNA isoforms from alternative tissue-specific transcriptional initiation. Physiol. Genomics. 2000, 3, 25-31. [CrossRef]

90. Phillips, M.I.; de Oliveira, E.M. Brain renin angiotensin in disease. J. Mol. Med. 2008, 86, 715-722. [CrossRef]

91. Rao, Y.; Chen, J.; Guo, Y.; Ji, T.; Xie, P. Rivaroxaban ameliorates angiotensin II-induced cardiac remodeling by attenuating TXNIP/Trx2 interaction in KKAy mice. Thromb. Res. 2021, 193, 45-52. [CrossRef]

92. Cheung, B.M.; Li, C. Diabetes and hypertension: Is there a common metabolic pathway? Curr. Atheroscler. Rep. 2012, 14, 160-166. [CrossRef] [PubMed]

93. Denver, P.; McClean, P. Distinguishing normal brain aging from the development of Alzheimer's disease: Inflammation, insulin signaling and cognition. Neural. Regen. Res. 2018, 13, 1719. [CrossRef] [PubMed]

94. Zhu, D.; Shi, J.; Zhang, Y.; Wang, B.; Liu, W.; Chen, Z.; Tong, Q. Central angiotensin II stimulation promotes $\beta$ amyloid production in Sprague Dawley rats. PLoS ONE 2011, 6, e16037. [CrossRef]

95. AbdAlla, S.; Lother, H.; el Missiry, A.; Langer, A.; Sergeev, P.; el Faramawy, Y.; Quitterer, U. Angiotensin II AT2 receptor oligomers mediate G-protein dysfunction in an animal model of Alzheimer disease. J. Biol. Chem. 2009, 284, 6554-6565. [CrossRef] [PubMed]

96. Cosarderelioglu, C.; Nidadavolu, L.S.; George, C.J.; Oh, E.S.; Bennett, D.A.; Walston, J.D.; Abadir, P.M. Brain Renin-Angiotensin System at the Intersect of Physical and Cognitive Frailty. Front. Neurosci. 2020, 14, 586314. [CrossRef] [PubMed]

97. Hodes, A.; Lichtstein, D. Natriuretic hormones in brain function. Front. Endocrinol. 2014, 5, 201. [CrossRef] [PubMed]

98. Sabayan, B.; van Buchem, M.A.; Sigurdsson, S.; Zhang, Q.; Meirelles, O.; Harris, T.B.; Gudnason, V.; Arai, A.E.; Launer, L.J. Cardiac and Carotid Markers Link with Accelerated Brain Atrophy: The AGES-Reykjavik Study (Age, Gene/Environment Susceptibility-Reykjavik). Arterioscler. Thromb. Vasc. Biol. 2016, 36, 2246-2251. [CrossRef]

99. Vandenberghe, R.; Rinne, J.O.; Boada, M.; Katayama, S.; Scheltens, P.; Vellas, B.; Tuchman, M.; Gass, A.; Fiebach, J.B.; Hill, D.; et al. Bapineuzumab for mild to moderate Alzheimer's disease in two global, randomized, phase 3 trials. Alzheimer's Res. Ther. 2016, 8, 18. [CrossRef] [PubMed]

100. Cannon, J.A.; Moffitt, P.; Perez-Moreno, A.C.; Walters, M.R.; Broomfield, N.M.; McMurray, J.J.V.; Quinn, T.J. Cognitive Impairment and Heart Failure: Systematic Review and Meta-Analysis. J. Card. Fail. 2017, 23, 464-475. [CrossRef] 
101. Rukavina Mikusic, N.L.; Kouyoumdzian, N.M.; Puyó, A.M.; Fernández, B.E.; Choi, M.R. Role of natriuretic peptides in the cardiovascular-adipose communication: A tale of two organs. Pflugers Arch. 2021, 1-15.

102. Fouda, A.Y.; Fagan, S.C.; Ergul, A. Brain Vasculature and Cognition. Arterioscler. Thromb. Vasc. Biol. 2019, 39, 593-602. [CrossRef] [PubMed]

103. Ritthaler, T.; Scholz, H.; Ackermann, M.; Riegger, G.; Kurtz, A.; Krämer, B.K. Effects of endothelins on renin secretion from isolated mouse renal juxtaglomerular cells. Am. J. Physiol. 1995, 268, F39-F45. [CrossRef]

104. Pohjolainen, L.; Easton, J.; Solanki, R.; Ruskoaho, H.; Talman, V. Pharmacological Protein Kinase C Modulators Reveal a Prohypertrophic Role for Novel Protein Kinase C Isoforms in Human Induced Pluripotent Stem Cell-Derived Cardiomyocytes. Front. Pharmacol. 2021, 11, 553852. [CrossRef] [PubMed]

105. Sharma, S.; Behl, T.; Kumar, A.; Sehgal, A.; Singh, S.; Sharma, N.; Hatia, S.; Al-Harrasi, A.; Bungau, S. Targeting Endothelin in Alzheimer's Disease: A Promising Therapeutic Approach. Biomed. Res. Int. 2021, 2021, 7396580. [CrossRef]

106. Wang, N.Y.; Li, J.N.; Liu, W.L.; Huang, Q.; Li, W.X.; Tan, Y.H.; Liu, F.; Song, Z.H.; Wang, M.Y.; Xie, N.; et al. Ferulic Acid Ameliorates Alzheimer's Disease-like Pathology and Repairs Cognitive Decline by Preventing Capillary Hypofunction in APP/PS1 Mice. Neurotherapeutics 2021, 18, 1064-1080. [CrossRef] [PubMed]

107. Alcendor, D.J. Dysregulation of Endothelin-1, Implications for Health Disparities in Alzheimer's Disease. J. Pers. Med. 2020, 10, 199. [CrossRef]

108. Berg, G.; Rybakova, D.; Fischer, D.; Cernava, T.; Vergès, M.C.; Charles, T.; Chen, X.; Cocolin, L.; Eversole, K.; Corral, G.H.; et al. Correction to: Microbiome definition re-visited: Old concepts and new challenges. Microbiome 2020, 8, 119. [CrossRef]

109. Sommer, F.; Bäckhed, F. The gut microbiota-masters of host development and physiology. Nat. Rev. Microbiol. 2013, 11, 227-238. [CrossRef] [PubMed]

110. Bonaz, B.; Bazin, T.; Pellissier, S. The vagus nerve at the interface of the microbiota-gut-brain axis. Front. Neurosci. 2018, $12,49$. [CrossRef] [PubMed]

111. Obrenovich, M.; Sankar Chittoor Mana, T.; Rai, H.; Shola, D.; Christopher, S.; McCloskey, B.; Levison, B.S. Recent findings within the microbiota- gut-brain-endocrine metabolic interactome. Pathol. Lab. Med. Int. 2017, 9, 21-30. [CrossRef]

112. Brierley, S.M.; Linden, D.R. Neuroplasticity and dysfunction after gastrointestinal inflammation. Nat. Rev. Gastroenterol. Hepatol. 2014, 11, 611-627. [CrossRef]

113. Jonsson, A.L.; Bäckhed, F. Role of gut microbiota in atherosclerosis. Nat. Rev. Cardiol. 2017, 14, 79. [CrossRef] [PubMed]

114. Everard, A.; Cani, P.D. Diabetes, obesity and gut microbiota. Best Pract. Res. Clin. Gastroenterol. 2013, 27, 73-83. [CrossRef] [PubMed]

115. Tilg, H.; Zmora, N.; Adolph, T.E.; Elinav, E. The intestinal microbiota fuelling metabolic inflammation. Nat. Rev. Immunol. 2019, 2019, 1-15. [CrossRef]

116. Muscogiuri, G.; Cantone, E.; Cassarano, S.; Tuccinardi, D.; Barrea, L.; Savastano, S.; Colao, A. Gut microbiota: A new path to treat obesity. Int. J. Obes. Suppl. 2019, 9, 10-19. [CrossRef]

117. Cani, P.D.; Van Hul, M.; Lefort, C.; Depommier, C.; Rastelli, M.; Everard, A. Microbial regulation of organismal energy homeostasis. Nat. Metab. 2019, 1, 34. [CrossRef]

118. Geurts, L.; Neyrinck, A.M.; Delzenne, N.M.; Knauf, C.; Cani, P.D. Gut microbiota controls adipose tissue expansion, gut barrier and glucose metabolism: Novel insights into molecular targets and interventions using prebiotics. Benef. Microbes. 2014, 5, 3-17. [CrossRef]

119. Van Dyken, P.; Lacoste, B. Impact of Metabolic Syndrome on Neuroinflammation and the Blood-Brain Barrier. Front. Neurosci. 2018, 12, 930. [CrossRef]

120. Heiss, C.N.; Mannerås-Holm, L.; Lee, Y.S.; Serrano-Lobo, J.; Håkansson Gladh, A.; Seeley, R.J.; Drucker, D.J.; Bäckhed, F.; Olofsson, L.E. The gut microbiota regulates hypothalamic inflammation and leptin sensitivity in Western diet-fed mice via a GLP-1R-dependent mechanism. Cell Rep. 2021, 35, 109163. [CrossRef]

121. Peng, J.; Xiao, X.; Hu, M.; Zhang, X. Interaction between gut microbiome and cardiovascular disease. Life Sci. 2018, $214,153-157$. [CrossRef]

122. Santisteban, M.M.; Qi, Y.; Zubcevic, J.; Kim, S.; Yang, T.; Shenoy, V.; Cole-Jeffrey, C.T.; Lobaton, G.O.; Stewart, D.C.; Rubiano, A.; et al. Hypertension-linked pathophysiological alterations in the gut. Circ. Res. 2017, 120, 312-323. [CrossRef]

123. Tanaka, M.; Itoh, H. Hypertension as a metabolic disorder and the novel role of the gut. Curr. Hypertens. Rep. $2019,21,63$. [CrossRef] [PubMed]

124. Bryniarski, M.A.; Hamarneh, F.; Yacoub, R. The role of chronic kidney disease-associated dysbiosis in cardiovascular disease. Exp. Biol. Med. 2019, 244, 514-525. [CrossRef]

125. Oliveira Andrade, J.M.; de Farias Lelis, D.; Mafra, V.; Cota, J. The Angiotensin Converting Enzyme 2 (ACE2), Gut Microbiota, and Cardiovascular Health. Protein Pept. Lett. 2017, 24, 827-832. [CrossRef] [PubMed]

126. Dewan, S.; Zheng, S.; Xia, S.; Bill, K. Senescent remodeling of the immune system and its contribution to the predisposition of the elderly to infections. Chin. Med. J. 2012, 125, 3325-3331. [PubMed]

127. Snarr, B.D.; Qureshi, S.T.; Sheppard, D.C. Immune Recognition of Fungal Polysaccharides. J. Fungi. 2017, 3, 47. [CrossRef]

128. Kowalski, K.; Mulak, A. Brain-Gut-Microbiota Axis in Alzheimer's disease. J. Neurogastroenterol. Motil. 2019, 25, 48-60. [CrossRef]

129. Wang, H.; Yang, F.; Xin, R.; Cui, D.; He, J.; Zhang, S.X.; Sun, Y. The gut microbiota attenuate neuroinflammation in manganese exposure by inhibiting cerebral NLRP3 inflammasome. Biomed. Pharmacother. 2020, 129, 110449. [CrossRef] 
130. Kim, M.S.; Kim, Y.; Choi, H.; Kim, W.; Park, S.; Lee, D.; Kim, D.K.; Kim, H.J.; Choi, H.; Hyun, D.W.; et al. Transfer of a healthy microbiota reduces amyloid and tau pathology in an Alzheimer's disease animal model. Gut 2020, 69, 283-294. [CrossRef]

131. Mezö, C.; Dokalis, N.; Mossad, O.; Staszewski, O.; Neuber, J.; Yilmaz, B.; Schnepf, D.; de Agüero, M.G.; Ganal-Vonarburg, S.C.; Macpherson, A.J.; et al. Different effects of constitutive and induced microbiota modulation on microglia in a mouse model of Alzheimer's disease. Acta Neuropathol. Commun. 2020, 8, 119. [CrossRef] [PubMed]

132. Shen, H.; Guan, Q.; Zhang, X.; Yuan, C.; Tan, Z.; Zhai, L.; Hao, Y.; Gu, Y.; Han, C. New mechanism of neuroinflammation in Alzheimer's disease: The activation of NLRP3 inflammasome mediated by gut microbiota. Prog. Neuropsychopharmacol. Biol. Psychiatry 2020, 100, 109884. [CrossRef] [PubMed]

133. Joachim, C.L.; Mori, H.; Selkoe, D.J. Amyloid beta-protein deposition in tissues other than brain in Alzheimer's disease. Nature 1989, 341, 226-230. [CrossRef] [PubMed] 